\title{
In vitro investigation of food effects on human gut microbiota
}

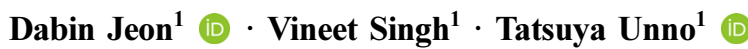

\section{In vitro 상에서 식품이 장내미생물에 미치는 영향}

\author{
전다빈 ${ }^{1} \cdot$ 싱그 비니트 ${ }^{1} \cdot$ 운노 타쯔야 $^{1}$
}

Received: 4 January 2021 / Accepted: 1 February 2021 / Published Online: 31 March 2021

(C) The Korean Society for Applied Biological Chemistry 2021

\begin{abstract}
Recent gut microbiota studies have revealed the important roles of gut microbiota for our health. Increasing numbers of health functional foods have been developed every year. Development of functional food often includes ex- and invivo experiment to verify the beneficial effects of the functional food. To investigate effects of functional food on gut microbiota, animal models were often conducted. Beneficial effects of food can be evaluated based on h ow gut microbiota was shifted by food, which results in either increase in beneficial bacteria, decrease in potentially pathogenic bacteria or both. As animal experiments are generally time-consuming and laborious, we investigate how well in-vitro investigation of fecal microbiota may reflect dietary health benefits. Here, we tested 15 kinds of diets using two human subjects' fecal materials. Our results showed varying gut microbiota shifts according to diets, which suggested generally known beneficial diets (i.e. Kimchi, Chunggukjang) increased Lactobacillus and Bifidobacterium. Therefore, we suggest that in vitro fecal microbiota analysis could be used to evaluate beneficial effects of diets. Moreover, this method may be ideal to establish personalized diet.
\end{abstract}

Keywords Differential abundance analysis $\cdot$ Fecal fermentation - Gastrointestinal digestion - Gut microbiota $\cdot$ Personal diet

Tatsuya Unno $(\triangle)$

E-mail: tatsu@jejunu.ac.kr

${ }^{1}$ Faculty of Biotechnology, School of life sciences, SARI Jeju National University, Jeju 63243, Republic of Korea

This is an Open Access article distributed under the terms of the Creative Commons Attribution Non-Commercial License (http://creativecommons. org/licenses/by-nc/3.0/) which permits unrestricted non-commercial use, distribution, and reproduction in any medium, provided the original work is properly cited.

\section{서 론}

차세대염기서열분석(Next generation sequencing, NGS)의 개발 은 비배양성 미생물을 포함하여 수백만 마리의 미생물을 동시 에 screening하는 것을 가능하게 했다. 대부분의 장내미생물이 비배양성으로 관련 연구진행에 어려움이 있었기에 NGS의 개발 은 이에 대한 연구에 크게 기여하였다. 그에 따라 건강과 장내 미생물이 밀접한 관련이 있으며, 그러한 장내미생물의 중요한 역할에 대한 많은 보고가 있다. 특히 장내미생물은 숙주의 소 화효소로는 분해가 가능하지 않은 식이섬유를 포함한 음식물 성 분을 분해하여 단쇄지방산(Short chain fatty acids, SCFAs)을 생산한다[1]. 이러한 SCFAs는 신체 내에 에너지대사 조절[2], 면역반응 강화[3], 밀착연접 (Tight junction) 조절[4], 그리고 신 경기능 향상(reference)과 같은 다양한 기능이 있다고 보고되어 있다[5]. SCFA 중 acetate, butyrate, propionate는 장내미생물이 생산하는 주요 SCFAs이며, 그 양은 장내 총 SCFAs의 $90 \%$ 이 상을 차지한다[6]. 특히 butyrate는 결장(colon)내 에너지 공급 [7], 점액층(mucus layer) 형성[8], 결장내 $\mathrm{pH}$ 유지[9], 병원성 박테리아 감소, 장 투과성 조절[10] 등과 같이 다양하게 건강에 유익한 영향을 미친다고 보고되고 있다. 또한 장내 유익균의 증 가로 인한 항비만 효과[11], 항염증 효과[12,13], 그리고 심지어 스트레스 내성 효과[14]에 대한 보고가 있다. 장내미생물은 식 이 요법, 연령, 투약 유무, 유전적 차이 및 거주지역과 같은 다 양한 요인들의 영향을 받으며, 이 중 식이요법은 항생제를 제 외하고 장내미생물에 가장 큰 영향을 미치는 요소로 알려져 있 다[15]. 즉, 섭취하는 음식에 따라 장내미생물생태의 유형이 달 라지는 것이다. 단기간의 식단조절은 장내미생물생태에 크게 영 향을 주진 못하지만, 장기간 불균형 식단 섭취는 장내 dysbiosis 를 유발시킨다. 이에 따라 다양한 기능성 식품은 장내미생물의 불균형 회복에 도움을 주기 위해 개발되고 있다. 이러한 기능 성 식품은 생리활성 화합물(i.e. polyphenols)이 함유된 식품뿐만 아니라 건강에 유익한 효과를 갖는 균주를 뜻하는 probiotics, 
이러한 probiotics의 에너지원인 prebiotics, 이 둘을 합친 synbiotics 까지 포함한다. 이전의 연구들에서 이러한 기능성 식품들이 건 강한 장내미생물생태를 구성하는데 도움된다고 보고되고 있지 만, 실질적으로 이러한 기능성 식품이 모든 사람들에게 효과적 이라는 사실은 거의 입증되지 않았다. 기능성 식품의 효과를 입 증하기 위해서는 ex-, in-vivo 실험이 필요하며, 그로 인해 동물 실험을 이용한 장내미생물생태 분석이 많이 진행되고 있으나 동 물실험은 비용적, 시간적, 윤리적인 문제점을 가지고 있다. 또 한 일반적으로 미생물마다 선호하는 소화 기질이 다르기에 결 장에 도달한 섬유소는 장내미생물의 구성에 따라 다르게 분해 된다. 장내미생물 생태는 생체 지문이라고 불릴 정도로 사람마 다 다양하게 구성된다. 따라서 기능성 식품의 효과는 개인의 장 내미생물 생태에 따라 달라진다고 사료된다.

따라서 본 연구는 in vitro에서의 장내미생물생태 분석을 이 용한 식품 건강기능성 평가에 대한 가능성을 연구하고자 수행 하였다. 본 연구에서 사용한 in vitro system은 인체 소화과정을 모방한 Gastrointestinal digestion (GID)을 사용하였으며, 그로부 터 얻어지는 GID 산물을 Fecal fermentation (FF) 과정을 거쳤 다. 그에 따라 변화하는 장내미생물생태를 분석하여 개인별로 나타나는 식품 건강기능성을 평가하는 방법에 대한 가능성을 조 사하고자 한다.

\section{재료 및 방법}

\section{실험 재료}

실험에 이용된 주요 화학 약품과 소화효소는 Sigma-Aldrich (St. Louis, MO, USA)에서 구매하였다. 실험에 사용된 15가지 식품 들은 모두 시판중인 제품을 사용했다. 그 외의 실험기기 및 시 약은 별도로 기술하였다.

\section{In vitro Gastrointestinal digestion (GID)}

이전에 보고된 방법을 이용하여[16], 식품이 인체내에서 소화되 는 과정을 모방한 GID 과정을 통해 소화산물을 제조하였고. Simulated saline fluid (SSF), Simulated gastric fluid (SGF), Simulated intestinal fluid (SIF)도 그에 따라 제조하였다. Oral phase에서는 $5 \mathrm{~g}$ 의 식품 시료(액체의 경우 $5 \mathrm{~mL}$ )를 사용하였고, $3.5 \mathrm{~mL}$ 의 SSF, $0.5 \mathrm{~mL} \alpha$-amylase $(1,500 \mathrm{U} / \mathrm{mL}), 25 \mu \mathrm{L} 0.3 \mathrm{M}$ $\mathrm{CaCl}_{2}$, 그리고 증류수 $975 \mu \mathrm{L}$ 를 첨가하여 최종 부피를 $10 \mathrm{~mL}$ 로 맞춘 후 $\mathrm{pH}$ 7로 조절했다. 그 후 Shaking incubator를 이 용하여 $37^{\circ} \mathrm{C}$ 에서 2분 간 반응시켰다. Gastric phase에서는 반 응된 SSF용액 $(10 \mathrm{~mL})$ 과 $1.6 \mathrm{~mL}$ pepsin solution $(25,000 \mathrm{U} /$ $\mathrm{mL})$ 을 포함한 $\mathrm{SGF}$ 용액 $(10 \mathrm{~mL})$ 과 혼합 후 $\mathrm{pH} 2.5$ 로 조절하였 고, 그 후 Shaking incubator를 이용하여 $37^{\circ} \mathrm{C}$ 에서 2시간 동안 반응시켰다. 최종적으로 Intestinal phase에서는 반응된 SGF용액 $(20 \mathrm{~mL})$ 은 $5 \mathrm{~mL}$ pancreatin solution $(800 \mathrm{U} / \mathrm{mL})$ 과 $2.5 \mathrm{~mL}$ bile salt $(160 \mathrm{mM})$ 을 포함한 $11 \mathrm{~mL} \mathrm{SIF용액과} \mathrm{혼합} \mathrm{한} \mathrm{후,} 1 \mathrm{M}$ $\mathrm{NaOH}$ 을 사용하여 $\mathrm{pH}$ 7로 조절하여 Shaking incubator를 이용 하여 $37^{\circ} \mathrm{C}$ 에서 2 시간 동안 반응시켰다. 소화효소 반응 이후 식 품시료는 액체 질소에 넣어 동결시켜 효소반응을 중지시켰고, $20{ }^{\circ} \mathrm{C}$ 에 보관하여 이후 실험에 사용하였다.

\section{Fecal fermentation (FF)}

사용한 분변시료는 제주대학교 생명윤리위원회(IRB)의 승인을 받아 채취하였다(JJNU-IRB-2018-040-002). 분변시료는 당뇨나 암, 간질환과 같은 기저질환을 갖고 있지 않은 건강한 성인 남 성으로부터 기증받았으며, 실험에 참여한 피험자들은 채취 시점 으로부터 3개월 이내에 장내미생물에 영향을 줄 수 있는 항생 제, 술, 약품 등의 섭취를 하지 않은 사람으로 구성되었다. FF 과정은 이전에 연구되어 보고된 방법으로 수행되었고[17], 이에 따라 Basal Culturing medium $(\mathrm{BCM})$ 을 제조했다. 분변은 채취 하여 산소를 치환시킨 Phosphate buffered saline $(10 \% \mathrm{w} / \mathrm{v})$ 에 균질화 시킨 후 채로 걸러 anaerobic chamber (Bactron II, SHEL LAB, Cornelus, OR, USA)로 옮겨 혐기상태를 유지하였 다. 준비된 $\mathrm{BCM}$ 에 $10 \% \mathrm{w} / \mathrm{v}$ 로 분변시료를 분주한 뒤 동결 건 조된 GID 소화산물 $(10 \% \mathrm{w} / \mathrm{v})$ 첨가하였다. Fecal fermentation 은 $37^{\circ} \mathrm{C}$ 에서 2 시간 동안 진행하였고, triplicate로 실험을 진행 하였다. $\mathrm{FF}$ 반응 직후 액체질소에 넣어 동결시켜 장내미생물 반 응 및 변화를 중지시켰다. 그 후 $-80{ }^{\circ} \mathrm{C}$ 에 보관하며, 장내미생 물생태 분석에 이용하였다.

\section{DNA extraction and 16S rRNA gene sequencing}

장내미생물생태 분석을 위한 $\mathrm{dsDNA}$ 는 반응된 $\mathrm{FF}$ 산물로부터 추출되었다. 동결된 샘플은 얼음위에서 녹이고, 그 중 $1 \mathrm{~mL}$ 을 $10,000 \mathrm{rpm}$ 에서 10 분간 원심분리하였다. 샘플 상층액은 버리고, 남은 pellet으로부터 QIAamp PowerFecal Pro DNA Kit (QIagen, Hilden, Germany)을 이용하여 DNA를 추출하였으며, Qubit dsDNA HS assay kit (Invitrogen, Carlsbad, CA, $\mathrm{USA}$ )를 이용하여 $5 \mathrm{ng} / \mu \mathrm{L}$ 로 농도를 표준화 하였다. $16 \mathrm{~S} \mathrm{rRNA}$ 유전자 내 가변부위(Variable region) 중 V3-V4을 5'-TCGTCG GCAGCGTCAGATGTGTATAAGAGACAGCCTACGGGNGGC WGCAG; forward primer, 5'-GTCTCGTGGGCTCGGAGATG TGTATAAGAGACAGGACTACHVGGGTATCTAATCC; reverse primer로 polymerase chain reaction (PCR)를 이용하여 증폭시켰다. 이후의 MiSeq library 제작과정은 Illumina (San Diego, CA, USA)에서 제공하는 16S Metagenomic sequencing library preparation protocol을 참고하여 수행되었다. 제작한 MiSeq Library는 마크로젠(Seoul, South Korea)에 시퀀싱을 의 뢰하였으며, raw data를 받아 분석하였다.

시퀀스데이터는 Miseq SOP (https://mothur.org/wiki/miseq $\mathrm{sop} /$ )에 따라 Mothur software [18]를 사용하여 분석했다. 간단 하게 설명하자면 paired-end 형태로 얻어진 raw reads를 assemble하고, SILVA database version 138에 align하였고, rare sequence들은 'pre.cluster'을 사용하여 수정하였다. Operational taxonomic units (OTUs)는 opti.clust algorithm을 이용하여 97\% 유사성으로 계산되었으며[19], Bray-curtis index를 기반으 로 dissimilarity를 계산하여 2차원적 그래프인 Non-metric multidimensional scaling (NMDS)로 나타냈고[20], 유의적인 차 이를 나타내는 OTUs는 Linear discriminant analysis Effect Size (LEfse)를 이용하여 분석하였다[21]. Heatmap은 R software 에서 heatmap.2 package를 사용하여 시각화 하였다[22]. 


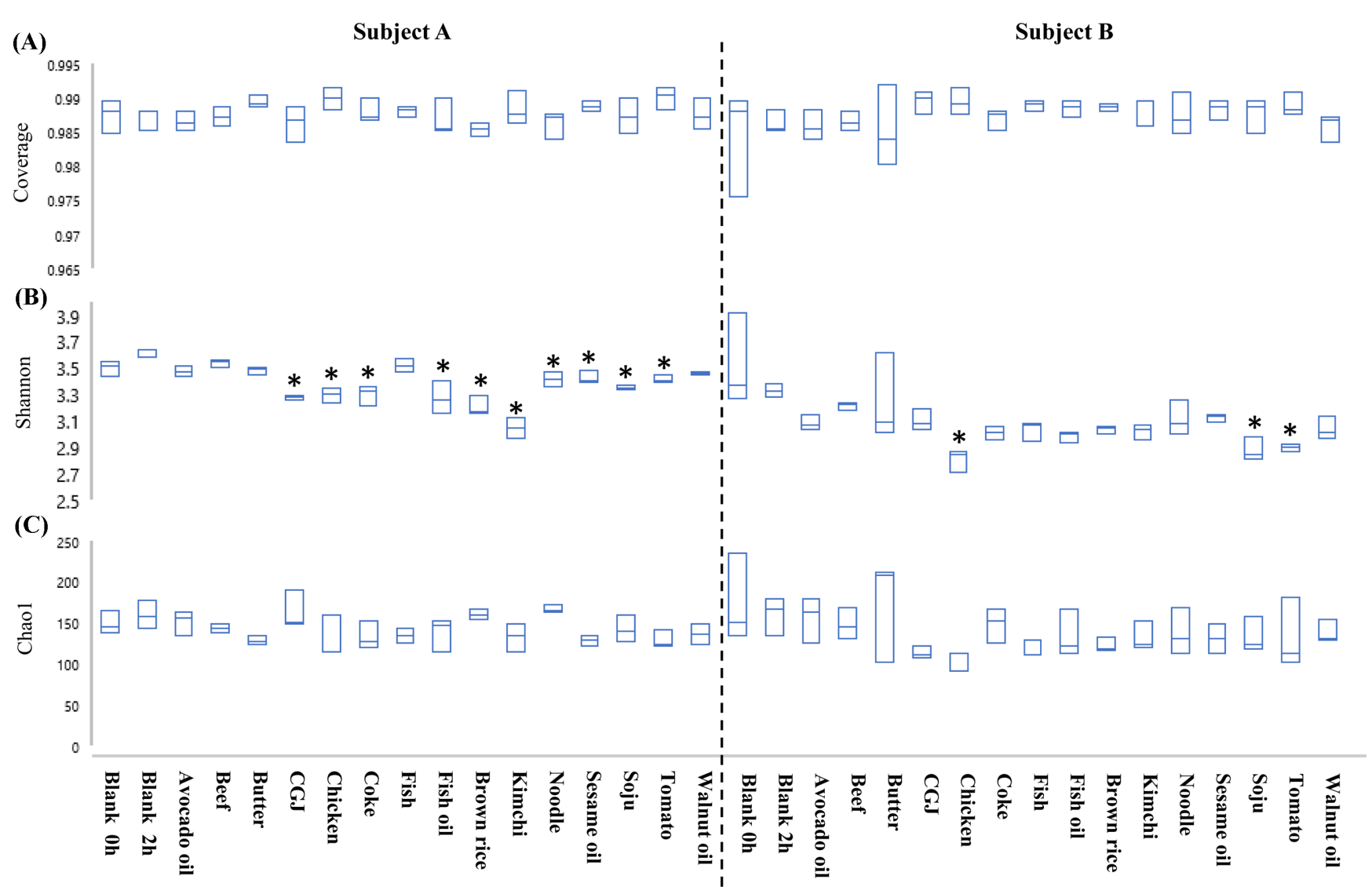

Fig. 1 Comparison of Coverage(A) and ecological indices for species evenness with Shannon (B) and species richness with Chao (C). CGJ: Chunggukjang, ${ }^{*} p<0.05$

\section{결과 및 고찰}

본 연구에서는 MiSeq을 수행하여 총 2,141,540개의 clean reads를 얻었고, 각 샘플당 2,500 reads를 임의적으로 선발하여 normalization을 수행하였다. 이 단계에서 Good's coverage의 $96 \%$ 이상인 것을 확인하였으며(Fig. 1A), 이는 normalization 이후에도 대부분의 OTUs가 손실되지 않았다는 것을 나타낸다. 종 균일도(evenness)를 나타내는 Shannon index는 피험자 $\mathrm{A}$ 에 서는 10 가지 식이, 피험자 $\mathrm{B}$ 에서는 3 가지 식이에 의해 유의적 으로 감소하는 것을 확인하였다 $(p<0.05)$ (Fig. $1 \mathrm{~B})$. 반면에 종 풍 부도(richness)를 나타내는 Chao index에서는 유의적인 차이가 없었다(Fig. 1C).

Phylum 수준에서 Taxonomic composition 분석은 비만을 나 타내는 지표중 하나로 알려진 Firmicutes/Bacteroidetes $(\mathrm{F} / \mathrm{B})$ 에 대해[23] 조사하기 위해 수행하였다. $\mathrm{F} / \mathrm{B}$ 비율은 피험자 $\mathrm{A}$ 에서 는 콜라, 소주, 피험자 $\mathrm{B}$ 에서는 토마토, 소주를 처리한 샘플에 서 유의적으로 증가하여 비만 관련 장내미생물이 증가하는 것 으로 나타났다 $(p<0.05)$ (Fig. 2, Fig. S1). 반면에, genus 수준에 서는 두 피험자 모두 Bacteroides, Blautia, Bifidobacterium의 높은 abundance가 확인되었다(Fig. S2). 또한 두 피험자가 갖고 있는 장내미생물의 abundance 차이를 조사한 결과에서는 피험 자 $\mathrm{A}$ 는 Bacteroides형의 enterotype, 피험자 $\mathrm{B}$ 는 Prevotella형의 enterotype임을 확인하였다(Fig. S4). 본 연구에서 2시간 동안
$\mathrm{FF}$ 배양을 시킨 식품처리군과 동일하게 배양한 비처리군인 Blank 샘플과의 abundance 차이도 관찰하였다. Figure 3은 각각 의 식품 처리에 의해 유의적으로 증가 또는 감소한 genera를 나 타냈다. 이 중 SCFAs를 생성한다고 알려진 유익균을 선별하여, 식품 처리가 유익균의 abundance에 미치는 영향을 Table 1에 요약했다. SCFAs 생성균으로 알려진 Blautia [24], Bifidobacterium [25], Faecalibacterium [26], Alistipes [27], Dialister [28], Lactobacillus [29], Bytyricicoccus [30], Odoribacter [31], Oscilibacter [32], Anaerostipes [33], Dorea [34] 및 Roseburia [28]를 포함 한 12 종의 genera가 확인되었다. Table 1은 피험자의 enterotype 에 따라 식품에 대한 반응이 다르게 나타나며, 특히 SCFAs 생 성균의 abundance에 영향을 미치는 것으로 확인 되었다. 따라 서 식이 요법이 각 사람에게 미치는 영향은 개별 장내미생물생 태 유형에 따라 달라 질것으로 예상된다.

본 연구에서 소주를 처리한 시료에서 알코올 소독에 내성이 있다고 알려진 Blautia의 증가를 확인하였다[35]. 각 피험자에서 대표적인 유익균으로 알려진 Bifidobacterium의 abundance를 관 찰하였다. 피험자 $\mathrm{A}$ 는 지방 식이(참기름, 아보카도유, 소고기)의 처리가 Bifidobacterium과 양의 상관관계가 있는 반면, 피험자 $\mathrm{B}$ 는 식이섬유(현미, 김치, 토마토)의 처리가 양의 상관관계가 있 음을 확인할 수 있었다. 김치를 첨가한 이후 Lactobacillus의 증 가는 피험자 $\mathrm{B}$ 에서만 관찰되었는데, 이는 피험자 $\mathrm{A}$ 의 장내미 생물생태에는 김치로부터 파생된 Lactobacillus 가 장 내에 군집 


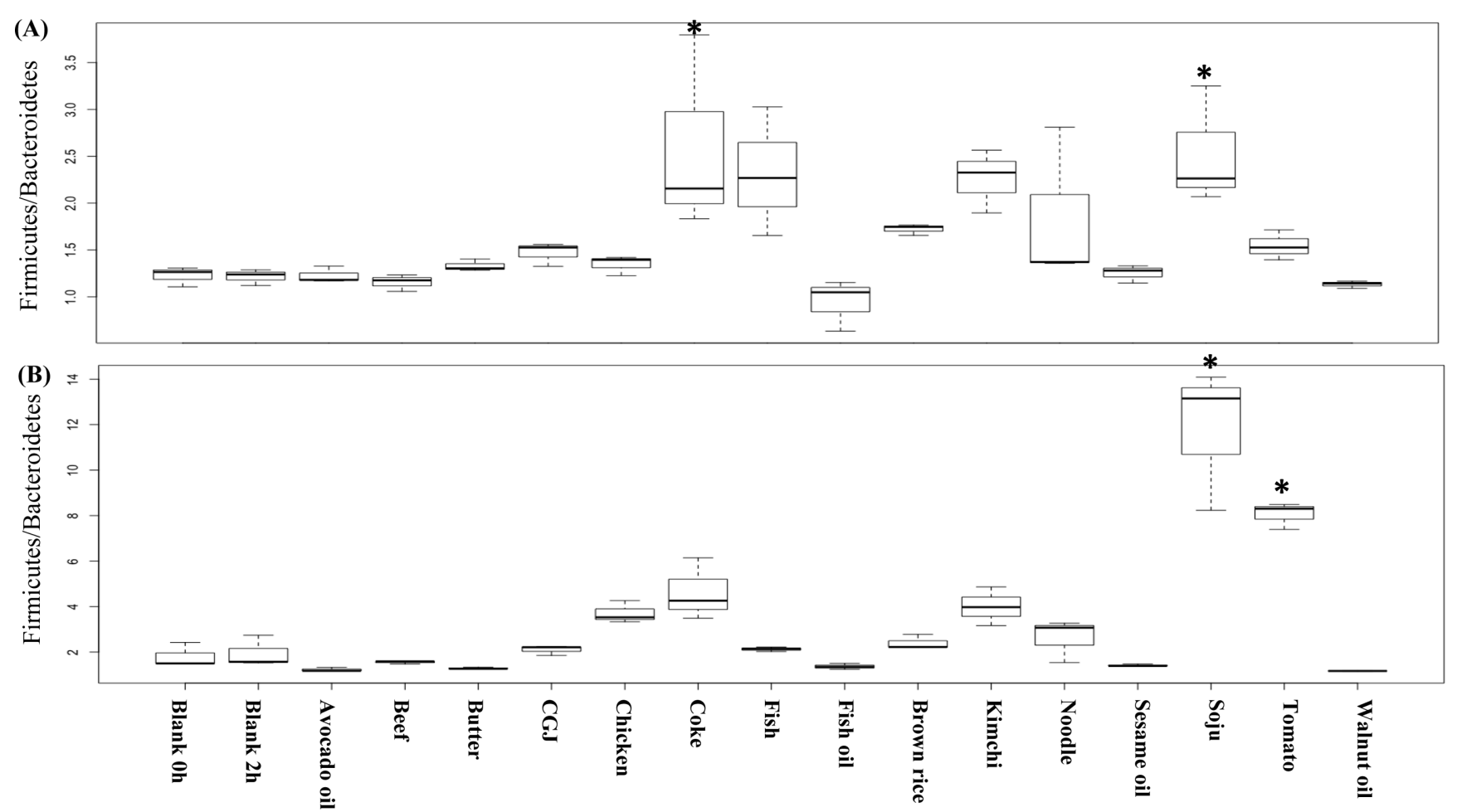

Fig. 2 Firmicutes/Bacteroidetes ratios after food treatments. CGJ: Chunggukjang, ${ }^{*} p<0.05$

형성이 되어 있지 않았을 것으로 사료된다. 한편, 많은 식품들 이 Alistipes, Dialister, Odoribacter, Oscilibacter, Dorea 및 Roseburia를 포함한 SCFA producer들을 감소시켰다. Figure 3 에서 Collinsella가 피험자 $\mathrm{A}$ 에서 유의적으로 증가한 것을 확인 할 수 있었는데 $(p<0.05)$, 이 미생물은 인체 내 장에서 잠재적 인 병원균으로 알려져 있다[36,37]. 또한 피험자 $\mathrm{A}$ 에서는 다양 한 식품 처리에 따라 Escherichia/Shigella가 유의적으로 증가하 는 것으로 확인되었는데 $(p<0.05)$, 이 미생물의 증가는 알코올성 지방간 질환과 관련이 있는 것으로 보고되어 있다[38]. 주요 butyrate-producer로 알려진 Faecalibacterium도 대부분의 식품 처리 이후 현저하게 감소하였지만 in vitro GID 과정에서의 bile salt 사용이 영향을 미쳤을 것으로 예상된다[39]. 이 결과는 위 실험에 사용하는 bile salt의 양을 제거하거나 줄이는 개선이 필 요함을 시사한다. 또한 Figure S5의 결과는 in vitro 배양만으로 도 여러 genera에 영향을 미친다는 것을 보여준다. 이 중 피험 자 $\mathrm{A}$ 에서 E. coli는 별도의 식품 첨가 없이도 증가하였으나, 식 품 처리 이후 보다 많이 증가하는 것을 확인하였다. 이는 식품 첨가와 in vitro 배양의 시너지 효과로 피험자 $\mathrm{A}$ 의 E. coli가 증가할 수 있는 가능성을 보여준다. Bray-curtis 거리를 기반으 로 식품 첨가 샘플 간의 유전적 거리를 분석했다. Figure S3의 결과는 in vitro 상에서 2시간 배양 후 식품 첨가가 Blank 샘플 보다 더 많은 장내미생물생태를 변화시켰음을 보여주며, 이는 in vitro 상에서의 장내미생물 생태에 대한 식품의 처리 효과가 분명했음을 시사한다. 또한 본 연구 결과를 볼 때 지방류와 소 고기 처리가 두 피험자에게 모두 유사한 장내미생물생태 로 변 화 시키는 것을 확인하였으며, 또한 소주, 콜라, 토마토 처리 이
후에서도 두 피험자 모두에서 유사한 장내 미생물생태 변화를 보였다. 피험자 $\mathrm{A}$ 에서 현미, 김치, 청국장이 유사한 장내미생물 생태 변화를 보였고, 피험자 $\mathrm{B}$ 에서는 현미, 면, 생선이 비슷한 결과를 나타내었다.

In vitro 상에서 GID-FF를 기반으로 하여 다양한 식이 유형 이 장내미생물생태에 미치는 영향을 조사하였고, 더 나아가 이 러한 영향에 대한 평가방법의 사용 가능성을 조사하였다. 비록 예비 연구 단계이지만, 본 연구결과는 다양한 장내미생물생태에 대한 식품의 반응 및 효과가 in vitro GID-FF 과정을 통해 평 가 될 수 있음을 시사하며, 실험적 방법에 대한 개선(즉, bile salts 영향 최소화 및 장내 미생물에 대한 in vitro 배양환경 최 적화)이 이뤄진다면, 동물실험을 대체할 수 있는 정확한 식품 영향 평가 모델로 발전할 수 있을 것으로 보여진다.

\section{초 록}

최근의 장내 미생물 연구에 따르면 우리의 건강에 대한 장내 미생물의 중요한 역할이 밝혀졌다. 이에 매년 다양한 건강 기 능 식품이 개발되고 있다. 기능성 식품의 개발에는 기능성 식 품의 유익한 효과를 확인하기위한 in-vivo 실험이 포함되는 경 우가 많다. 그 이유로 기능성 식품이 장내 미생물에 미치는 영 향을 조사하기 위해서 동물 실험을 자주 수행하고 있는 실정이 다. 식품의 유익한 효과는 장내 미생물 생태가 식품에 의해 이 동되어 유익한 박테리아의 증가, 잠재적인 병원성 박테리아의 감소 또는 둘 다에 따라 평가 될 수 있다. 동물 실험은 일반적 

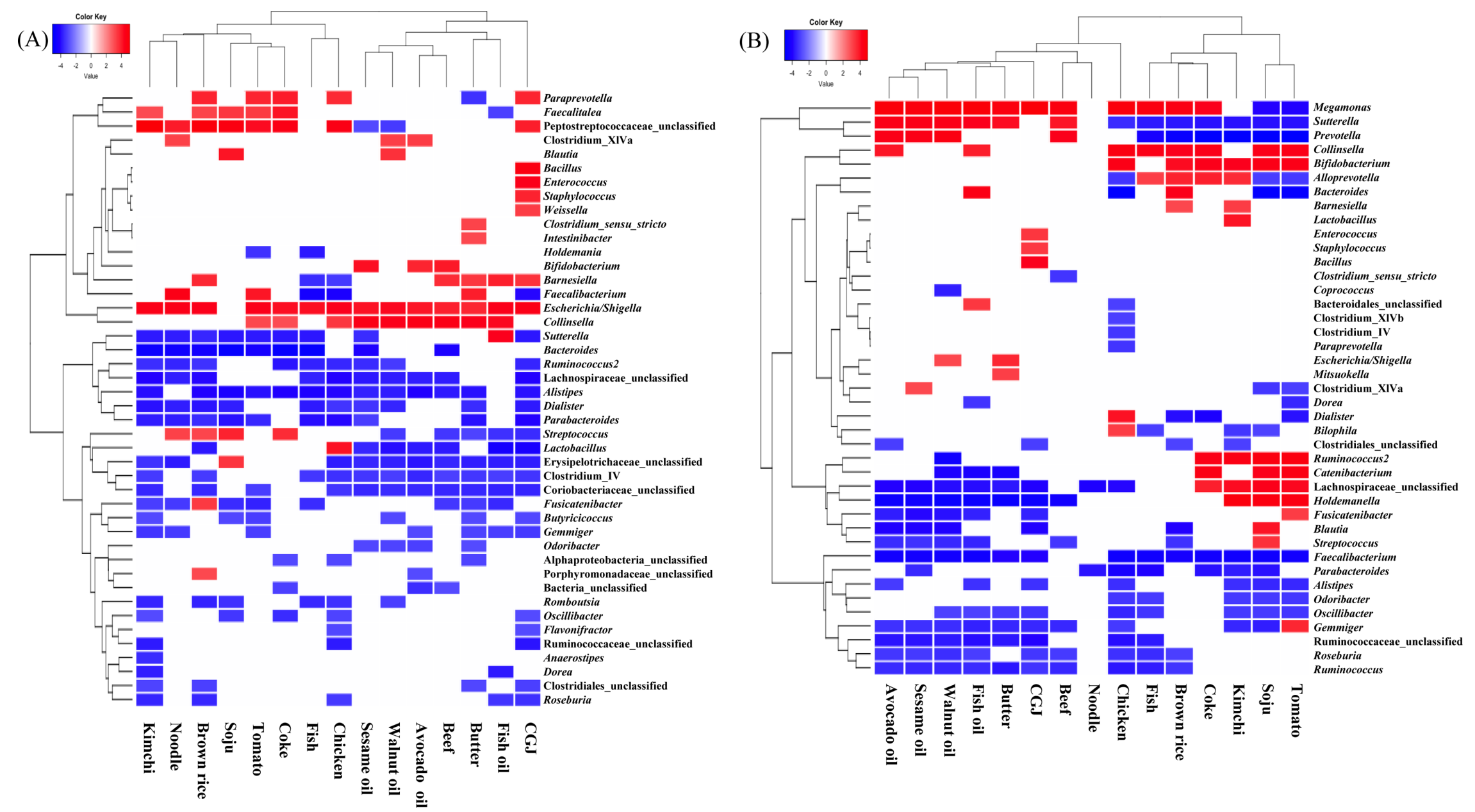

Fig. 3 Significantly increased and decreased genera by dietary supplementation for subject A (A) and B (B). CGJ: Chunggukjang 
Table 1 Differentially abundant genera of butyrate producers after addition of food treatments

\begin{tabular}{|c|c|c|c|c|}
\hline \multirow{2}{*}{ SCFA producers } & \multicolumn{2}{|c|}{ Increased } & \multicolumn{2}{|c|}{ Decreased } \\
\hline & Subject A & Subject B & Subject A & Subject B \\
\hline Blautia & Walnut oil, Soju & Soju & - & $\begin{array}{l}\text { Brown rice, Chunggukjang, } \\
\text { Avocado oil, Sesame oil, } \\
\text { Walnut oil }\end{array}$ \\
\hline Bifidobacterium & $\begin{array}{l}\text { Sesame oil, } \\
\text { Avocado oil, Beef }\end{array}$ & $\begin{array}{l}\text { Chicken, Brown rice, } \\
\text { Coke, Kimchi, Soju, } \\
\text { Tomato }\end{array}$ & - & - \\
\hline Faecalibacterium & Noodle, Tomato & - & Fish, Chicken, Chunggukjang & $\begin{array}{l}\text { All kinds of foods except Noodle, } \\
\text { Beef }\end{array}$ \\
\hline Alistipes & - & - & $\begin{array}{l}\text { All kinds of foods except Fish, } \\
\text { Noodle }\end{array}$ & $\begin{array}{l}\text { Avocado oil, Fish oil, } \\
\text { Chunggukjang, Chicken, } \\
\text { Kimchi, Soju, Tomato }\end{array}$ \\
\hline Dialister & - & Chicken & $\begin{array}{l}\text { Kimchi, Noodle, Brown rice, } \\
\text { Soju Fish, Chicken, Sesame oil, } \\
\text { Walnut oil, Butter, Chunggukjang }\end{array}$ & Brown rice, Coke, Tomato \\
\hline Lactobacillus & Chicken & Kimchi & $\begin{array}{l}\text { Sesame oil, Walnut oil, Avocado oil, } \\
\text { Beef, Fish oil, Chunggukjang }\end{array}$ & - \\
\hline Bytyricicoccus & - & - & $\begin{array}{l}\text { Kimchi, Soju, Tomato, Walnut oil, } \\
\text { Butter, Chunggukjang }\end{array}$ & - \\
\hline Odoribacter & - & - & $\begin{array}{l}\text { Sesame oil, Walnut oil, Avocado oil, } \\
\text { Butter }\end{array}$ & $\begin{array}{l}\text { Chicken, Fish, Kimchi, Soju, } \\
\text { Tomato }\end{array}$ \\
\hline Oscilibacter & - & - & $\begin{array}{l}\text { Kimchi, Soju, Coke, Chicken, } \\
\text { Chunggukjang }\end{array}$ & $\begin{array}{l}\text { Walnut oil, Fish oil, Butter, } \\
\text { Chunggukjang, Chicken, Fish, } \\
\text { Kimchi, Soju, Tomato }\end{array}$ \\
\hline Anaerostipes & - & - & Kimchi & - \\
\hline Dorea & - & - & Kimchi, Fish oil & Fish oil, Tomato \\
\hline Roseburia & - & - & $\begin{array}{l}\text { Kimchi, Brown rice, Chicken, Fish oil, } \\
\text { Chunggukjang }\end{array}$ & $\begin{array}{l}\text { Avocado oil, Sesame oil, Walnut } \\
\text { oil, Fish oil, Chunggukjang, Beef, } \\
\text { Chicken, Fish, Brown rice }\end{array}$ \\
\hline
\end{tabular}

으로 시간이 많이 걸리고 까다롭기 때문에 본 연구팀은 분변 미생물에 대한 in-vitro 연구로 식이 건강상의 이점을 얼마나 잘 반영하는지 조사했다. 본 연구에서는 두 사람의 배설물을 사용 하여 15 가지 음식이 장내미생물에 주는 영향을 조사했다. 결과 는 식단에 따라 다양한 장내 미생물 이동을 보여 주었으며, 이 는 일반적으로 알려진 유익한 식단(즉, 김치, 청국장)이 유산균 과 비피도 박테리움을 증가 시켰음을 확인했다. 따라서, 우리는 식이 요법의 유익한 효과를 평가하기 위해 체외 분변 미생물 균총 분석을 사용할 수 있다고 제안한다. 또한, 이 방법은 더 나아가 개인 맞춤형 식단을 설정하는 데 도움이 될 수 있다고 사료된다.

Keywords 맞춤형 식단 - 미생물 비교 분석 · 분변 발효 · 소 화모방 - 장내미생물

감사의 글 이 논문은 2016 년도 정부(교육부)의 재원으로 한국연구재단의 지원을 받아 수행된 기초연구사업임(2016R1A6A1A03012862).

\section{References}

1. Makki K, Deehan E C, Walter J, Bäckhed F (2018) The impact of dietary fiber on gut microbiota in host health and disease. Cell Host
Microbe 23: 705-715. doi:101016/jchom201805012

2. Koh A, De Vadder F, Kovatcheva-Datchary P, Bäckhed F (2016) From dietary fiber to host physiology: short-chain fatty acids as key bacterial metabolites. Cell 165: 1332-1345. doi:101016/jcell201605041

3. Qing Y, Xie H, Su C, Wang Y, Yu Q, Pang Q, Cui F (2019) Gut microbiome, short-chain fatty acids, and mucosa injury in young adults with human immunodeficiency virus infection. Dig Dis Sci 64: 18301843. doi:101007/s10620-018-5428-2

4. Tan J, McKenzie C, Potamitis M, Thorburn AN, Mackay CR, Macia L (2014) The role of short-chain fatty acids in health and disease. Adv Immunol 121: 91-119. doi:101016/B978-0-12-800100-400003-9

5. Byrne CS, Chambers ES, Morrison DJ, Frost G (2015) The role of short chain fatty acids in appetite regulation and energy homeostasis. Int $\mathrm{J}$ Obes 39: 1331-1338. doi:101038/ijo201584

6. Ríos-Covián D, Ruas-Madiedo P, Margolles A, Gueimonde M, De Los Reyes-gavilán CG, Salazar N (2016) Intestinal short chain fatty acids and their link with diet and human health. Front Microbiol 17: 185. doi:103389/fmicb201600185

7. Donohoe DR, Garge N, Zhang X, Sun W, O'Connell TM, Bunger MK, Bultman SJ (2011) The microbiome and butyrate regulate energy metabolism and autophagy in the mammalian colon. Cell Metabol 13: 517-526. doi:101016/jcmet201102018

8. Shimotoyodome A, Meguro S, Hase T, Tokimitsu I, Sakata T (2000) Short chain fatty acids but not lactate or succinate stimulate mucus release in the rat colon. Comp Biochem Physiol A Mol Integr Physiol 125: 525-531. doi:101016/S1095-6433(00)00183-5

9. Hamer HM, Jonkers DMAE, Venema K, Vanhoutvin SALW, Troost FJ, Brummer R-J (2008) The role of butyrate on colonic function. Aliment 
Pharmacol Ther 27: 104-119. doi:101111/j1365-2036200703562x

10. Canani RB, Di Costanzo M, Leone L, Pedata M, Meli R, Calignano A (2011) Potential beneficial effects of butyrate in intestinal and extraintestinal diseases. World J Gastroenterol 28: 1519-1528. doi:103748/wjgv17i121519

11. Ley RE (2010) Obesity and the human microbiome. Curr Opin Gastroenterol 26: 5-11. doi:101097/MOG0b013e328333d751

12. Strober W (2013) Impact of the gut microbiome on mucosal inflammation. Trends Immunol 34: 423-430. doi:101016/jit201307001

13. Kim J, Choi JH, Ko G, Jo H, Oh T, Ahn B, Unno T (2020) AntiInflammatory Properties and Gut Microbiota Modulation of Porphyra tenera Extracts in Dextran Sodium Sulfate-Induced Colitis in Mice. Antioxidants 9: 988. doi:103390/antiox9100988

14. Foster JA, Rinaman L, Cryan JF (2017) Stress the gut-brain axis: regulation by the microbiome. Neurobiol Stress 19: 124-136. doi:101016/jynstr201703001

15. Xu Z, Knight R (2015) Dietary effects on human gut microbiome diversity. $\mathrm{Br} \quad \mathrm{J}$ Nutr. https://pubmed.ncbi.nlm.nih.gov/25498959/. Accessed 11 Dec 2014. doi:101017/S0007114514004127

16. Minekus M, Alminger M, Alvito P, Ballance S, Bohn T, Bourlieu C, Carriere F, Boutrou R, Corredig M, Dupont D, Dufour C, Egger L, Golding M, Karakaya S, Krkhus B, Le Feunteun S, Lesmes U, Macierzanka A, Mackie A, Marze S, McClements DJ, Menard O, Recio I, Santos CN, Singh RP, Vegarud GE, Wickham MSJ, Weitschies W, Brodkorb A (2014) A standardised static in vitro digestion method suitable for food-an international consensus. Food Funct. 5: 1113. doi:101039/C3FO60702J

17. Moon J S, Li L, Bang J, Han N S (2016) Application of in vitro gut fermentation models to food components: A review. Food Sci Biotechnol 25: 1-7. doi:101007/s10068-016-0091-x

18. Schloss PD, Westcott SL, Ryabin T, Hall JR, Hartmann M, Hollister EB, Lesniewski RA, Oakley BB, Parks DH, Robinson CJ (2009) Introducing mothur: open-source, platform-independent, community-supported software for describing and comparing microbial communities. Appl Environ Microbiol 75: 7537-7541. doi:101128/AEM01541-09

19. Westcott SL, Schloss PD (2017) OptiClust, an improved method for assigning amplicon-based sequence data to operational taxonomic units. mSphere 8;2(2):e00073-17. doi:101128/mSphereDirect00073-17

20. Clarke KR, Somerfield PJ, Chapman MG (2006) On resemblance measures for ecological studies, including taxonomic dissimilarities and a zero-adjusted Bray-Curtis coefficient for denuded assemblages. J Exp Mar Biol Ecol 330: 55-80. doi:101016/jjembe200512017

21. Segata N, Izard J, Waldron L, Gevers D, Miropolsky L, Garrett W S, Huttenhower C (2011) Metagenomic biomarker discovery and explanation. Genome Biol R60. doi:101186/gb-2011-12-6-r60

22. De Micheaux PL, Drouilhet R, Liquet B (2013) The R software. Springer. New York

23. Koliada A, Syzenko G, Moseiko V, Budovska L, Puchkov K, Perederiy V, Gavalko Y, Dorofeyev A, Romanenko M, Tkach S(2017) Association between body mass index and Firmicutes/Bacteroidetes ratio in an adult Ukrainian population. BMC Microbiol 120. doi:101186/s12866-0171027-1

24. Banerjee S, Sar A, Misra A, Pal S, Chakraborty A, Dam B (2018) Increased productivity in poultry birds by sub-lethal dose of antibiotics is arbitrated by selective enrichment of gut microbiota, particularly shortchain fatty acid producers. Microbiology 164. doi:101099/mic0000597

25. Belenguer A, Duncan SH, Calder AG, Holtrop G, Louis P, Lobley GE, Flint HJ (2006) Two routes of metabolic cross-feeding between Bifidobacterium adolescentis and butyrate-producing anaerobes from the human gut. Appl Environ Microbiol 72: 3593-3599. doi:101128/ AEM7253593-35992006
26. Machiels K, Joossens M, Sabino J, De Preter V, Arijs I, Eeckhaut V, Ballet V, Claes K, Van Immerseel F, Verbeke K (2014) A decrease of the butyrate-producing species Roseburia hominis and Faecalibacterium prausnitzii defines dysbiosis in patients with ulcerative colitis. Gut 63: 1275-1283. doi:101136/gutjnl-2013-305799

27. Oliphant K, Allen-Vercoe E (2019) Macronutrient metabolism by the human gut microbiome: major fermentation by-products and their impact on host health. Microbiome. 91. doi:101186/s40168-019-0704-8

28. Louis P, Hold GL, Flint HJ (2014) The gut microbiota, bacterial metabolites and colorectal cancer. Nat Rev Microbiol 12: 661-672. doi:101038/nrmicro3344

29. Wullt M, Hagslätt ML J, Odenholt I, Berggren A (2007) Lactobacillus plantarum $299 \mathrm{v}$ enhances the concentrations of fecal short-chain fatty acids in patients with recurrent clostridium difficile-associated diarrhea. Dig Dis Sci 52: 2082-2086. doi:101007/s10620-006-9123-3

30. Geirnaert A, Steyaert A, Eeckhaut V, Debruyne B, Arends J B, Van Immerseel F, Boon N, Van de Wiele T (2014) Butyricicoccus pullicaecorum, a butyrate producer with probiotic potential, is intrinsically tolerant to stomach and small intestine conditions. Anaerobe 30: 70-74. doi:101016/janaerobe201408010

31. Hiippala K, Barreto G, Burrello C, Diaz-Basabe A, Suutarinen M, Kainulainen V, Bowers JR, Lemmer D, Engelthaler DM, Eklund KK, Facciotti F, Satokari R (2020) Novel Odoribacter splanchnicus Strain and Its Outer Membrane Vesicles Exert Immunoregulatory Effects in vitro Front Microbiol doi:103389/fmicb2020575455

32. Tong AJ, Hu RK, Wu LX, Lv XC, Li X, Zhao LN, Liu B (2020) Ganoderma polysaccharide and chitosan synergistically ameliorate lipid metabolic disorders and modulate gut microbiota composition in high fat diet-fed golden hamsters. J Food Biochem. doi:101111/jfbc13109

33. Parada Venegas D, De la Fuente MK, Landskron G, González MJ, Quera R, Dijkstra G, Harmsen HJM, Faber KN, Hermoso MA (2019) Short chain fatty acids (SCFAs)-mediated gut epithelial and immune regulation and its relevance for inflammatory bowel diseases. Front Immunol 10: 277. doi:103389/fimmu201900277

34. Bang SJ, Kim G, Lim MY, Song EJ, Jung DH, Kum JS, Nam YD, Park CS, Seo, DH (2018) The influence of in vitro pectin fermentation on the human fecal microbiome. Amb Express 8: 98. doi:101186/s13568-0180629-9

35. Afouda P, Hocquart M, Pham TP, Kuete E, Ngom II, Dione N, Valles C, Bellali S, Lagier JC, Dubourg G, Raoult D (2020) Alcohol pretreatment of stools effect on culturomics. Sci Rep 10. doi:101038/s41598-02062068-x

36. Frost F, Storck LJ, Kacprowski T, Gärtner S, Rühlemann M, Bang C, Franke A, Volker U, Aghdassi AA, Steveling A, Mayerle J, Weiss FU, Homuth G, Lerch MM (2019) A structured weight loss program increases gut microbiota phylogenetic diversity and reduces levels of Collinsella in obese type 2 diabetics: A pilot study. PLoS One 14: e0219489. doi:101371/journalpone0219489

37. Gomez-Arango LF, Barrett HL, Wilkinson SA, Callaway LK, McIntyre HD, Morrison M, Dekker Nitert M (2018) Low dietary fiber intake increases Collinsella abundance in the gut microbiota of overweight and obese pregnant women. Gut Microbes 9: 189-201. doi:101080/ 1949097620171406584

38. Miura K, Ohnishi H (2014) Role of gut microbiota and Toll-like receptors in nonalcoholic fatty liver disease. World J Gastroenterol 21: 7381-7391. doi:103748/wjgv20i237381

39. Foditsch C, Santos TM, Teixeira AG, Pereira RV, Dias JM, Gaeta N, Bicalho RC (2014) Isolation and characterization of Faecalibacterium prausnitzii from calves and piglets. PloS one 9: e116465. doi:101371/ journalpone 0116465 